\title{
Guilt from Inaction: Discussion on the Moderated Mediation Effect of Cause-Related Product Hedonism, Country-of-origin Image, and Anticipatory Guilt on Purchase Intention
}

\author{
Chi-Cheng Luan ${ }^{1}$, Su Zhang ${ }^{1, *}$ and Tianchen Lin $^{1}$ \\ ${ }^{1}$ Department of Management Science, National Yang Ming Chiao Tung University, Hsinchu, 20010, Taiwan \\ *Corresponding authors.Email: 1198224181@qq.com
}

\begin{abstract}
Ad messages in cause-related marketing (CRM) motivate consumers' anticipatory guilt if they do not do good things (i.e., do not purchase cause-related products). According to cognitive dissonance theory, consumers tend to purchase cause-related products in order to reduce anticipatory guilt for maintaining cognitive consistency. We further hypothesize that in CRM ads, the positive effect of product hedonism on anticipatory guilt is moderated by country-of-origin (COO) image. When consumers perceive greater hedonic $\mathrm{COO}$ image from the ad, they are more likely to purchase cause-related products through anticipatory guilt due to product hedonism. 182 subjects were randomly assigned to 2 (product hedonism: low vs. high) $\times 2$ (COO image: low hedonic vs. high hedonic) between-subjects design. The results confirm our moderated mediation model. In addition, we find that the moderating effect of COO image does not lead to consumers' negative responses toward CRM because of too strong anticipatory guilt. Thus, this research can suggest effective CRM strategies for firms.
\end{abstract}

Keywords: cause-related marketing, anticipatory guilt, product hedonism, country-of-origin image

\section{INTRODUCTION}

Cause-related marketing is the essential part of Corporate Social Responsibility. Specifically, it means that enterprises' products or services are directly related with particular charities. Every time consumers purchase their products or services, enterprises will donate part of their benefits gained from the products or services to those charities. During the recent two decades, the discussion of related issues has been a key research trend at the same time of enjoying rapid development in Asia[2].

Enterprises often use guilt appeal in their cause-related marketing to stimulate consumers' support for their causerelated products[3]. The related research shows that maintaining cognitive consistency is significant to meet individual basic need[4]. These advertisements not only promote the donation of specific items, but imply the negative social consequence of not doing responding consumption. Once recognizing these hints, consumers will have the feeling of anticipatory guilt. And they will tend to reduce such feeling with practical purchase to tackle the cognitive dissonance[3]. However, anticipatory guilt is not always positively correlated with consumers' attitudes and behaviors. Even in certain situation, too much anticipatory guilt will lead to consumers' rejection[5]. Thus, it is of great significance to research the boundary conditions of anticipatory guilt effectiveness in cause-related marketing[2].

There are two research drawbacks in the former causerelated marketing literature. Firstly, even though the former empirical researches have verified that hedonic feature of cause-related products has positive impacts on consumers' purchase intention and anticipatory guilt is vital to improve the intention[2, 5]. But the experimental samples are not from Asia, so there is some doubt whether the cognitive process is appropriate for consumers from Asia. Secondly, the former researches failed to take country-of-origin image(COO image) into the consideration. But in terms of product hedonism, country of brand leaves a stereotyped impression on the public, which may enhance consumers' cognition with product hedonism of cause-related products. So, this author put forward a moderated mediation model, which explored the interaction between product hedonism and COO image, and the influence of anticipatory guilt on consumers' purchase intention for cause-related products. 


\section{LITERATURE DISCUSSION AND RESEARCH HYPOTHESIS}

\subsection{The Hedonic Feature of Cause-Related Products Helps Improve the Purchase Intention}

When evaluating hedonic products or practical products, consumers have quite different mental process. The consumption motivation of hedonic products is usually related with entertainment and enjoyment, and its evaluation is based on emotions; while the consumption motivation of practical products is likely to depend on consumers' appeal for the function of products, so its evaluation is based on goals[6]. Since cause-related marketing aims at motivating consumers to purchase products against their original consumption goals[7], those hedonic products are less likely to make consumers feel dissonance with their original consumption goals, which leads to an increasing purchase intention for hedonic products in cause-related marketing.

Given that a number of products enjoy both hedonic and practical value in practice, the author holds that it is of more practical value to discuss the effects of product hedonism on cause-related marketing. So, when reading cause-related marketing advertisement, consumers have less cognition dissonance and have higher purchase intention if the products in the cause-related marketing are more hedonic. So, the research put forward that:

H1: Under the circumstance of reading cause-related marketing advertisements, consumers are more willing to purchase those products that are more hedonic.

\subsection{The Mediating Role of Anticipatory Guilt}

A person will have a sense of guilt when he or she recognizes that his or her behavior is against the personal code or social norm. The sense of guilt can be further classified into anticipatory guilt and reactive guilt[8]. The former is from the possible negative consequence of their inaction; while the latter is from the negative consequence of their practical immoral behaviors. In the practice of cause-related marketing, enterprises usually make the marketing more efficient by using the advertisement to motivate the anticipatory guilt[3]. For example, coffee brands like Cafédirect point out the harm of unfair coffee trade on small farmers and environment on the wrapping paper, which can promote consumers to buy those coffee identified by fair trade.

Cognitive dissonance theory explains why anticipatory guilt can make consumers be more willing to purchase causerelated products[4]. It points out that maintaining cognitive consistency is significant to meet individual basic need. When helping the disadvantaged is regarded as one kind of social norm in society, individuals will internalize the norm, and any cognition or behavior against the norm will lead to a sense of guilt. At the same time of promoting the specific items of donation, cause-related marketing also implies the potential negative consequence on society due to the inaction (no purchase). In order to reduce the anticipatory guilt, consumers tend to buy cause-related products.

By referring to the literature about product hedonism, the author holds that product hedonism can enhance consumers' anticipatory guilt when they are reading causerelated marketing advertisements. Hedonic consumption is usually contrary to the thrift proposed by social norm, so consumers will unconsciously make negative self attribution at the time of hedonic consumption[9]. Both the implication of cause-related marketing and negative self attribution brought by hedonic consumption will make consumers more easily anticipate that their behaviors will be against the social norm. As a result, the anticipated guilt will be greatly improved. The more intense the anticipated guilt is, the higher the purchase intention will be. They will be more willing to purchase cause-related products to reduce the cognition dissonance and maintain the cognitive consistency. To sum up, the author put forward that:

$\mathrm{H} 2$ : Under the circumstance of reading cause-related marketing advertisements, the anticipated guilt plays an mediating role in the influence on the purchase intention by product hedonism.

\subsection{The Moderating Role of COO Image}

The stereotyped impression of country of brand will affect consumers' cognition with the features of products[10]. For example, those consumers who can't speak French will sense the higher hedonic feature of a product when they see the brand name written in French in the advertisement[11]. The author finds that for those products that are more hedonic, consumers' cognition about product hedonism will be magnified especially when country of origin image gives more hedonic feeling. Then, it will strengthen consumers' cognition dissonance and anticipatory guilt. On the contrary, for those with lower hedonic degree and limited hedonic feeling brought by COO image, consumers won't have significant anticipatory guilt. To sum up, the author put forward that:

H3: Under the circumstance of reading cause-related marketing advertisements, COO image moderates the relationship between product hedonism and anticipatory guilt. When COO image leaves a stronger hedonic feeling on people, product hedonism will positively affect the anticipatory guilt. When the hedonic feeling is not so strong, the positive influence of product hedonism on the anticipatory guilt will be also reduced.

Combined with the previous assumptions, the author further put forward that:

H4: Under the circumstance of reading cause-related marketing advertisements, the interaction between the product hedonism and $\mathrm{COO}$ image will indirectly affect purchase intention though the mediator variable anticipated guilt.

The theoretical framework of this research is shown in Figure 1. 


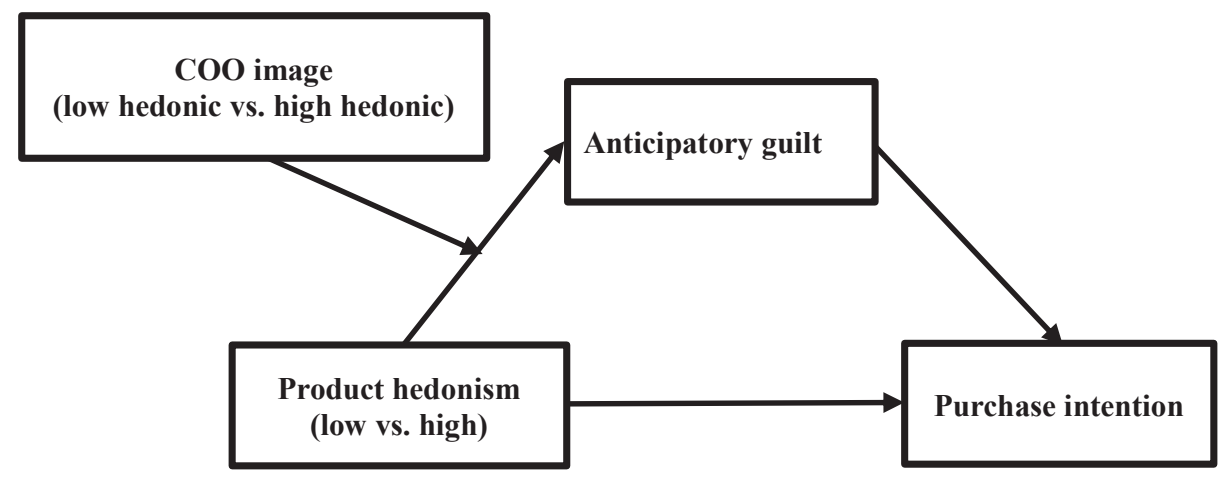

Figure 1. Theoretical framework

\section{RESEARCH METHODS}

\subsection{Experiment Design and Samples}

The experiment design of the research adopted 2 (product hedonism: low vs. high $) \times 2$ (COO image: low hedonic vs. high hedonic). And the subjects were randomly assigned into four experimental groups.

The 249 participants were from a university in Taiwan, and they were asked to click the link to enter the online questionnaire. The subjects were be randomly assigned by the pre-determined program. There were 67 invalid questionnaires due to the insufficient attention. As a result, there were 182 valid questionnaires. The average age of subjects is 26.42, and there are 118 men, accounting for $64.8 \%$. Over half $(56 \%)$ of the subjects have earned bachelor's degree.

\subsection{Experiment Manipulation}

The manipulation change of product hedonism was from Chang et al. (2018) [3]. The subjects were asked to look at a marketing poster. Under the circumstance of low product hedonism, on the poster was the yogurt without fruit, and the words below the picture emphasized that the yogurt had low fat, probiotics and nutrient. Under the circumstance of high product heroism, on the poster was the yogurt with fruit, and the words below the picture emphasized that the yogurt was full of milk flavor and fruit was added to enrich its texture (refer to appendix).

The manipulation change of $\mathrm{COO}$ image was from Leclerc et al. (1994) [11]. Under the circumstance of low hedonic, the yogurt brand name in the marketing poster was "super+pasture", a fictitious brand written in Chinese. In addition, the subjects were told that the brand came from Taiwan. Under the circumstance of high hedonic, the yogurt brand name in the marketing poster was "Mathisé", a fictitious brand written in French. In addition, the subjects were told that the brand came from France.

\subsection{Experiment Procedures}

The subjects were told that the research had two parts, aiming at learning consumers' attitude towards certain brand products. In the first part, the subjects had to imagine that they noticed a marketing poster with the brand of "super+pasture" or "Mathisé" when shopping in the supermarket. And the product hedonism was represented through pictures and texts. After reading the poster, the subjects were told about the country of brand and they were supposed to finish the related testing questions. In the second part, the subjects were told that the brand was involved in the activity of "purchase leading to donation". Every time its yogurt was sold ( $¥ 40$ ), the company would donate milk that equals to one fourth of the price of the yogurt (¥10) to Children’s Education Fund, which could be used to help children living in remote countryside. The former research showed that $25 \%$ was widely accepted and consumers would carefully think about the cause-related marketing information[3]. In the end, the subjects were asked to answer the questions about anticipatory guilt, purchase intention, control variable and attention testing.

\subsection{Variable Measure}

The scale of Dahl et al. (2005) was adopted to test anticipatory guilt[12], including two questions and using 7point Likert scale as the measure tool $(\alpha=.947)$. The scale of Green and Peloza (2014) was adopted to test the purchase intention[13], including three questions and using 7-point Likert scale as the measure tool $(\alpha=.942)$.

By combining with the former studies, the research chose perceived cause-business fit (including two questions, 7point Likert scale, $\alpha=.863$ ), perceived CSR trustworthiness (including three questions, 7-point Likert scale, $\alpha=.850$ ), ethnocentrism (including four questions, 7-point Likert scale, $\alpha=.869$ ), interdependent trait (including four questions, 7-point Likert scale, $\alpha=.798$ ) and independent trait (including four questions, 7-point Likert scale, $\alpha=$ $.722)$ as the control variables. 


\section{RESEARCH RESULT AND ANALYSIS}

\subsection{Manipulation Testing}

The manipulation of product hedonism was successful, and the t-test results showed that the subjects have significantly higher cognition with hedonic products than practical ones $(\mathrm{M}=4.470>\mathrm{M}=2.530, \mathrm{p}<.001)$. The manipulation of $\mathrm{CCO}$ image was successful, and the t-test results showed that the subjects gave far higher remarks for "the hedonic index" with "Mathisé" than the other one $(\mathrm{M}=.011>\mathrm{M}=$ $-.591, \mathrm{p}<.05)$.

\subsection{Reliability and Validity Testing}

The overall fit of the conceptual model was pretty good. The value of $\chi 2$ was significant, and CFI $=.944, \mathrm{RMSEA}=.066$, $\mathrm{SRMR}=0.062$. The reliability degree was pretty good, and both the Cronbach's $\alpha$ and composite reliability of every construct were higher than 0.7 . The convergence validity was also good, and the standardized factor loading of every choice in every construct was higher than 0.4 and has significant meaning. The average variance extracted (ACE) of every construct was more than 0.5 , and the component reliability was higher than 0.7 . The discriminant validity was pretty good. The square root of ACE in every construct was larger than the correlation coefficient of the construct and others. In addition, the correlation coefficient of constructs was lower than 0.8 , showing no effect of collinearity.

\subsection{Hypothesis Testing}

At first, Multiple Linear Regression was used in this research with purchase intention as the dependent variable, product hedonism as the independent variable (low hedonic $=0$, high hedonic $=1$ ). And the control variables included perceived cause-business fit, perceived CSR trustworthiness, ethnocentrism, interdependent trait and independent trait. The testing result showed that it was corresponding with the anticipatory result. Product hedonism has positive influence on purchase intention $(b=$ $.124, \mathrm{t}=2.224, \mathrm{p}<.05$ ). Compared with lower hedonism, the subjects under the circumstance of reading marketing with higher product hedonism had higher purchase intention, which could be supported by H1. In addition, within the control variables, perceived cause-business fit (b $=.244, \mathrm{t}=3.554, \mathrm{p}<.001)$ and perceived CSR trustworthiness $(\mathrm{b}=.410, \mathrm{t}=5.994, \mathrm{p}<.001)$ have significant influence on purchase intention, which was corresponding with the result of former researches.

Then, Hayes' PROCESS Model 7 was adopted in this research to make 5,000 samples at the $95 \%$ confidence level, with the purchase intention as the dependent variable, product hedonism as the independent variable, anticipatory guilt as mediator variable, $\mathrm{COO}$ image as moderator variable (low hedonic $=0$, high hedonic $=1$ ), perceived cause-business fit, perceived CSR trustworthiness, ethnocentrism, interdependent trait and independent trait as control variables. The testing result showed that it was corresponding with the anticipatory result. When the brand was from France, product hedonism could significantly has an indirect affect purchase intention through influencing anticipatory guilt; while if the brand was from Taiwan $(\mathrm{b}=$ $.319, \mathrm{SE}=.105,95 \% \mathrm{CI}:[.139, .567])$, the indirect effect was not significant $(\mathrm{b}=.067, \mathrm{SE}=.085,95 \% \mathrm{CI}:[-.083$, .255]). The results could be supported by $\mathrm{H} 2$ and $\mathrm{H} 3$. More importantly, the index of moderated mediation manifested that the indirect effects were quite different under different country of brand (Index $=2.252, \mathrm{SE}=.120,95 \% \mathrm{CI}:[.036$, $.512]$ ), which could be supported by $\mathrm{H} 4$. The data collection tested by the moderated mediation model is shown in Table 1.

Table 1. Moderated mediation result

\begin{tabular}{|c|c|c|c|c|c|c|c|c|}
\hline & \multicolumn{4}{|c|}{ Anticipatory guilt } & \multicolumn{4}{|c|}{ Purchase intention } \\
\hline & $b$ & SE & $t$ & $p$ & $b$ & SE & $t$ & $p$ \\
\hline Constant & -1.173 & .715 & -1.640 & .103 & -.793 & .456 & -1.740 & .084 \\
\hline ETH & .246 & .084 & 2.912 & .004 & .015 & .056 & .276 & .783 \\
\hline IT1 & .180 & .107 & 1.680 & .095 & .005 & .069 & .073 & .942 \\
\hline IT2 & .028 & .081 & .339 & .735 & .106 & .053 & 2.010 & .046 \\
\hline PCT & .241 & .132 & 1.831 & .069 & .483 & .087 & 5.573 & .000 \\
\hline PCF & .172 & .107 & 1.611 & .110 & .222 & .070 & 3.161 & .002 \\
\hline PT & .224 & .273 & .820 & .414 & .132 & .134 & .987 & .325 \\
\hline CI & .107 & .277 & .386 & .700 & & & & \\
\hline INT & .840 & .391 & 2.147 & .033 & & & & \\
\hline $\mathrm{AG}$ & & & & & .299 & .048 & 6.234 & .000 \\
\hline $\mathrm{R} 2$ & \multicolumn{4}{|c|}{.342} & \multicolumn{4}{|c|}{.594} \\
\hline $\mathrm{F}$ & \multicolumn{4}{|c|}{$11.256 * * *$} & \multicolumn{4}{|c|}{$36.308 * * *$} \\
\hline
\end{tabular}

1. Interaction: product hedonism $\times \mathrm{COO}$ image; Mediator: anticipatory guilt

2. ETH: ethnocentrism; IT1: interdependent trait; IT2: independent trait; PCT: perceived CSR trustworthiness; PCF: perceived cause-business fit; PT: product type; $\mathrm{CI}$ : $\mathrm{COO}$ image; $\mathrm{AG}$ : anticipatory guilt

3. $* * * p<.001 ; * * p<.01 ; * p<.05$ 


\section{DISCUSSION}

\subsection{The Contribution of Theory and Practice}

In terms of the theory contribution, firstly, the research has increased the cognition of the relationship between product hedonism and anticipatory guilt under the circumstance of cause-related marketing by introducing $\mathrm{COO}$ hedonic image. Country of brand leaves a stereotyped impression on people in terms of hedonic feeling, which has a positive effect on regulating the influence of product hedonism on anticipated guilt. Secondly, what matters far more is that the former researches show that the excessive guilt appeal in cause-related marketing will lead to consumers' maladaptive responses. Consumers will suspect the sincerity of enterprises on participating in the charity and then reduce their purchase intention $[3,5]$. However, in this research, the interactive effect of product hedonism and COO image doesn't trigger such maladaptive response. The author thinks that, in the consumers' cognition, product hedonism and $\mathrm{COO}$ image are not likely to be subjectively manipulated by enterprises, and they belong to the objective attribute of products. That is to say, enterprises make full use of product hedonism and $\mathrm{COO}$ image to manipulate the anticipated guilt, which is so subtle that can successfully avoid triggering consumers' suspicion.

In terms of practice contribution: firstly, the research has helped enterprises find two manipulation methods to make cause-related marketing more efficient. Enterprises can enhance consumers' purchase intention by highlighting the product hedonism or emphasizing related $\mathrm{COO}$ image in their marketing advertisement description. Secondly, although this research finds that the anticipatory guilt can be increased by manipulating product hedonism and $\mathrm{COO}$ image and consumers don't have maladaptive responses, it's better for enterprises to use the methods carefully. In fact, the research just adopts text description to motivate consumers' anticipatory guilt for not purchasing causerelated products. If enterprises use more vivid pictures or videos about remote children's hard life, it's better to reduce the description about the product hedonism and hide information of COO image that can bring higher hedonic feelings, which can avoid potential negative effects.

\subsection{Research Limits and Advice on Future Researches}

The existing research limits are as follows. Firstly, the samples chosen in this research are oriented with the young, so the later research can collect and analyze more samples covering all age groups so as to enhance the external validity of the conclusion in this research. Secondly, the experiments in this research were finished online, which has some discrepancy with consumers' practical shopping experience in the offline supermarkets, so the later research can choose the location in the real supermarket or offline simulated environment. Thirdly, this research just made use of text description to motivate consumers' anticipatory guilt due to the inaction. If enterprises use more vivid pictures or videos about remote children's hard life, the future research can make a further exploration to discuss whether the subtle manipulation with product hedonism and COO image will lead to consumers' maladaptation.

\section{CONCLUSION}

With the combination of cognitive dissonance theory, the author explored how product hedonism and COO image affect consumers' purchase intention for cause-related products by means of influencing anticipatory guilt. To be specific, the research shows that under the circumstance of reading cause-related marketing advertisements, the anticipatory guilt brought by the inaction (not purchasing cause-related products) will be positively affected by product hedonism. It's because the negative self attribution brought by product hedonism will enhance consumers' cognition of being against social norm. During the cognition process, COO image is another pivotal influencing factor. When $\mathrm{COO}$ image leaves a stronger hedonic feeling on people, it will positively affect the anticipatory guilt. When the hedonic feeling is not so strong, the positive influence of product hedonism on the anticipatory guilt will be also reduced. As the anticipatory guilt increases, consumers will have higher purchase intention to cause-related products in order to maintain the cognitive consistency (reduce the guilt).

\section{REFERENCES}

[1] Garriga, E., \& Melé, D.. Corporate social responsibility theories: Mapping the territory. Journal of business ethics, 53(1-2), 51-71, 2004.

[2] Coleman, J. T., Royne, M. B., \& Pounders, K. R.. Pride, Guilt, and Self-Regulation in Cause-Related Marketing Advertisements. Journal of Advertising, 49(1), 34-60, 2020.

[3] Chang, C. T.. Guilt appeals in cause-related marketing: The subversive roles of product type and donation magnitude. International Journal of Advertising, 30(4), 587-616, 2011.

[4] Harmon-Jones, E., \& Mills, J.. An introduction to cognitive dissonance theory and an overview of current perspectives on the theory. In E. Harmon-Jones (Ed.), Cognitive dissonance: Reexamining a pivotal theory in psychology. American Psychological Association, pp. 3-24, 2019. https://doi.org/10.1037/0000135-001

[5] Singh, J., \& Crisafulli, B.. How intensity of causerelated marketing guilt appeals influences consumers: the roles of company motive and consumer identification with the brand. Journal of Advertising Research, 60(2), 148-162, 2020.

[6] Dhar, R., \& Wertenbroch, K.. Consumer choice between hedonic and utilitarian goods. Journal of Marketing Research, 37(1), 60-71, 2000.

[7] Strahilevitz, M., \& Myers, J. G.. Donations to Charity as Purchase Incentives: How Well They Work 
May Depend on What You Are Trying to Sell. Journal of Consumer Research, 24(4), 434-446, 1998.

[8] Theotokis, A., \& Manganari, E.. The impact of choice architecture on sustainable consumer behavior: The role of guilt. Journal of Business Ethics, 131(2), 423-437, 2015.

[9] Fishbach, A., Friedman, R. S., \& Kruglanski, A. W.. Leading us not into temptation: Momentary allurements elicit overriding goal activation. Journal of Personality and Social Psychology, 84(2), 296, 2003.

[10] Liu, S. S., Johnson, K. F., \& Johnson, K. F.. The automatic country-of-origin effects on brand judgments. Journal of Advertising, 34(1), 87-97, 2005.

[11] Leclerc, F., Schmitt, B. H., \& Dubé, L.. Foreign Branding and Its Effects on Product Perceptions and Attitudes. Journal of Marketing Research, 31(2), 263270, 1994.

[12] Dahl, D. W., Honea, H., \& Manchanda, R. V.. Three Rs of interpersonal consumer guilt: Relationship, reciprocity, reparation. Journal of Consumer Psychology, 15(4), 307-315, 2005

[13] Green, T., \& Peloza, J.. How do consumers infer corporate social responsibility? The role of organisation size. Journal of Consumer Behaviour, 13(4), 282-293, 2014.

Appendix: Poster used to manipulate product hedonism and $\mathrm{COO}$ image

Low product hedonism $\times$ High hedonic COO image
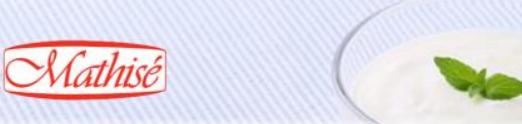

1 優格由富含䟥和維生素的營着強化牛奶所製成

除此之外, 我們研㢭出的特殊低脂眍方通能娍少 $99 \%$ 的脂肪成份

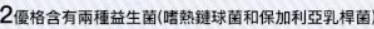

有助於保持你的渴道內菌群的健康平衡。

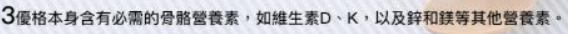

有助於人緹的骨骼強壯, 而且剖於成年人的效果更佳。
High product hedonism $\times$ High hedonic COO image

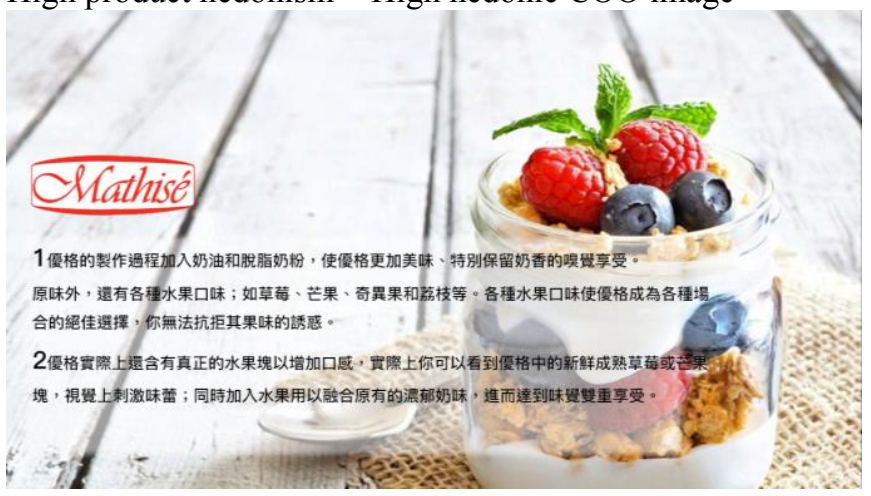

Low product hedonism $\times$ Low hedonic COO image

\section{優圽場}

1 優格由富含釷和維生素的營奉強化牛奶所慗成。

除此之外, 我佩研登出的特殊低脂配方遗能浱少 $99 \%$ 的脂肪成份。

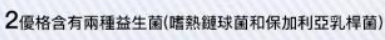

有助於保持你的腸道內菌群的健康平衡。

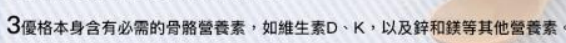

有助於人體的骨骼強壯, 而且對於成年人的效果更佳。

Low product hedonism $\times$ Low hedonic $\mathrm{COO}$ image

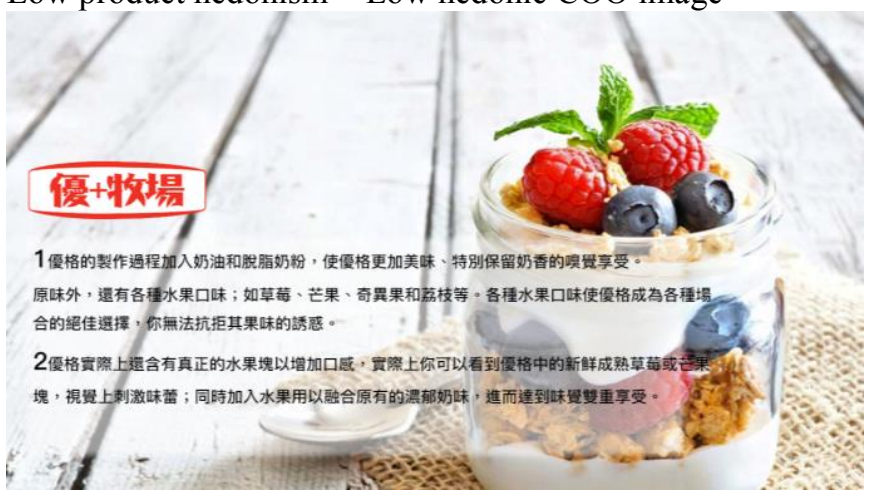

